\title{
Did sulfate availability facilitate the evolutionary expansion of chlorophyll a+c phytoplankton in the oceans?
}

\section{Citation}

Ratti, S., A. H. Knoll, and M. Giordano. 2011. “Did Sulfate Availability Facilitate the Evolutionary Expansion of Chlorophyll A+c Phytoplankton in the Oceans?" Geobiology 9, no. 4: 301-312.

\section{Published Version}

doi:10.1111/j.1472-4669.2011.00284.x

\section{Permanent link}

http://nrs.harvard.edu/urn-3:HUL.InstRepos:13031960

\section{Terms of Use}

This article was downloaded from Harvard University's DASH repository, and is made available under the terms and conditions applicable to Open Access Policy Articles, as set forth at http:// nrs.harvard.edu/urn-3:HUL.InstRepos:dash.current.terms-of-use\#OAP

\section{Share Your Story}

The Harvard community has made this article openly available.

Please share how this access benefits you. Submit a story.

Accessibility 
1 Did sulfate availability facilitate the evolutionary expansion of

2 chlorophyll a+c phytoplankton in the oceans?

3

4

5

6

7 Running title: Sulfate and evolution of chlorophyll a $+c$ phytoplankton 


\section{ABSTRACT}

During the Mesozoic Era, dinoflagellates, coccolithophorids and diatoms became prominent primary producers in the oceans, succeeding an earlier biota in which green algae and cyanobacteria had been proportionally more abundant. This transition occurred during an interval marked by increased sulfate concentration in seawater. To test whether increasing sulfate availability facilitated the evolutionary transition in marine phytoplankton, the cyanobacterium Synechococcus sp., the green alga Tetraselmis suecica, and three algae containing chlorophyll a+c (the diatom Thalassiosira weissflogii, the dinoflagellate Protoceratium reticulatum, and the coccolithophorid Emiliania huxleyi) were grown in media containing $1,5,10,20$ or $30 \mathrm{mM} \mathrm{SO}_{4}{ }^{2-}$. The cyanobacterium and the green alga showed no growth response to varying $\left[\mathrm{SO}_{4}{ }^{2-}\right]$. In contrast, the three chlorophyll a+c algae showed improved growth with higher $\left[\mathrm{SO}_{4}{ }^{2-}\right]$, but only up to $10 \mathrm{mM}$. The chlorophyll a+c algae, but not the green alga or cyanobacterium, also showed lower $\mathrm{C}: \mathrm{S}$ with higher $\left[\mathrm{SO}_{4}{ }^{2-}\right]$. When the same experiment was repeated in the presence of a ciliate predator (Euplotes sp.), T. suecica and $T$. weissflogii increased their specific growth rate in most treatments, whereas the growth rate of Synechococcus sp. was not affected or decreased in the presence of grazers.

In a third experiment, T. suecica, T. weissflogii, P. reticulatum, and Synechococcus sp. were grown in conditions approximating modern, earlier Paleozoic and Proterozoic seawater. In these treatments, sulfate availability, nitrogen source, metal availability and $\mathrm{P}_{\mathrm{CO} 2}$ varied. Monospecific cultures exhibited their highest growth rates in the Proterozoic treatment. In mixed culture, $T$. weissflogii outgrew other species in modern seawater and $T$. suecica outgrew the others in Paleozoic water. Synechococcus sp. grew best in Proterozoic seawater, but did not outgrow eukaryotic species in any treatment. Collectively, our results suggest that secular increase in seawater $\left[\mathrm{SO}_{4}{ }^{2-}\right]$ may have facilitated the evolutionary expansion of chlorophyll a+c phytoplankton, but probably not to the exclusion of other biological and environmental factors. 


\section{INTRODUCTION}

42 In the productive waters that bathe continental shelves, three groups of algae with chloroplasts

43 containing chlorophyll a and chlorophyll c dominate photosynthesis: diatoms, dinoflagellates,

44 and coccolithophorids. Despite their abundance and diversity, these taxa are relative newcomers

45 to marine ecosystems (Falkowski et al., 2004). Both conventional fossils and preserved lipids

46 suggest that in Proterozoic oceans cyanobacteria and other photosynthetic bacteria fueled

47 ecosystems, whereas cyanobacteria and green algae were major primary producers in Paleozoic

48 oceans (Knoll et al., 2007; Kodner et al., 2008; Johnston et al., 2009). Dinoflagellates may have

49 been the first of the major chlorophyll a+c phytoplankton to appear; purported dinocysts have

50 been reported from Paleozoic rocks, and low abundances of dinosterane, the geologically stable

51 form of dinosterol synthesized by dinoflagellates, have been reported from Cambrian deposits

52 (Molodowan \& Talyzina, 1998). Despite this, unambiguous dinocysts and shales with abundant

53 dinosterane occur only in Triassic and younger successions, indicating, at the very least, that

54 photosynthetic dinoflagellates assumed a globally important and persistent role in marine primary production only at this time (Knoll et al., 2007). The fossil record of diatoms extends only to the latest Jurassic Period (Harwood et al., 2004), and the group rose to ecological prominence only in later Cretaceous and Paleogene oceans (Kooistra et al., 2007). Similarly, the oldest coccoliths occur in later Triassic rocks, and coccolithophorids became widespread only during the Cretaceous Period (Bown et al., 2004).

At least three classes of hypothesis are available to explain the observed stratigraphic succession of primary producers. Perhaps seawater chemistry has changed through time in a

62 way that favored successive phytoplankton groups. Quigg et al. (2003), for example, proposed

63 that decreasing iron availability associated with the increasing ventilation of deep oceans

64 provided a competitive edge to the chlorophyll a+c algae that dominate modern shelf production,

65 due to the lower requirement of their plastids for Fe compared to that green algae. Alternatively, 66 we might hypothesize that a Mesozoic increase in grazing pressure by micrograzers favored the modern phytoplankton biota - sort of a microscopic version of Vermeij’s (1977) hypothesis that

68 escalating predation drove marked evolutionary changes in Mesozoic marine animals. It is also 69 possible that changing phytoplankton composition principally reflects the individual adaptations 70 of photosynthetic clades rather than ecosystem-wide causes and effects. Kooistra et al. (2007), 
71 for example, have enumerated cell biological adaptations that favor diatom abundance, while

72 Bowler et al. (2010) have discussed much the same thing from a genomic perspective. The

73 hypotheses, of course, are not mutually exclusive.

74 Only through careful experimentation can we begin to sort out these views of long term

75 phytoplankton evolution. In this paper, we take a first step in this direction, reporting the

76 outcome of experiments designed to test the specific hypothesis that increasing concentration of

77 seawater sulfate favored chlorophyll a+c algae with low $\mathrm{C}$ to $\mathrm{S}$ ratios. As detailed in the

78 following section, this hypothesis is motivated by the stratigraphic correlation between the

79 taxonomic and ecological expansion of chlorophyll a+c phytoplankton and an increase of marine

80 sulfate levels to their current, historically high levels. In our experiments, single species stand in

81 for entire divisions, undoubtedly a gross oversimplification. Nonetheless, they provide starting

82 points for experimental tests of physiological links between phytoplankton evolution and

83 environmental history.

GEOCHEMICAL AND PHYSIOLOGICAL BACKGROUND

\section{Sulfate abundance in time and space}

If phytoplankton composition has changed through time, so, too, has the chemical state of the oceans that support its growth. Sulfate abundances in ancient seawater have been inferred in several ways: experimentally observed correlation between S isotopic fractionation and sulfate abundance at very low $\left[\mathrm{SO}_{4}{ }^{2-}\right.$, dynamic models of observed secular variations in the isotopic

94 composition of sulfate in seawater, and, in younger records, reconstruction of seawater chemistry

95 from fluid inclusions in evaporite minerals. While all of these proxies are subject to error, they

96 collectively provide a consistent picture of seawater $\left[\mathrm{SO}_{4}{ }^{2-}\right]$ through geologic history. Sulfate

97 abundance was probably less than $200 \mu \mathrm{M}$ in the Archean oceans that sustained the first marine

98 cyanobacteria (Habicht et al., 2002), and [ $\left.\mathrm{SO}_{4}{ }^{2-}\right]$ increased to no more than 1-5 $\mathrm{mM}$ in the

99 Proterozoic oceans within which green algae rose to ecological prominence (Shen et al., 2002;

100 Canfield, 2004; Kah et al., 2004). Sulfate abundance may have reached values as high as $15 \mathrm{mM}$ 101 in later Ediacaran oceans, but declined again into the Cambrian (Horita et al., 2002; Petrychenko 
102 et al., 2005). Analyses of fluid inclusions in salt crystals indicate Cambrian $\left[\mathrm{SO}_{4}{ }^{2-}\right]$ in the range 103 of 3-12 mM; models based on $\mathrm{C}$ and $\mathrm{S}$ isotopic variations suggest [ $\left.\mathrm{SO}_{4}{ }^{2-}\right]$ near the lower end of 104 this range (Gill et al., 2011).

105 Sulfate abundance appears to have remained below about $10 \mathrm{mM}$ until the Carboniferous 106 Period, when it increased to $>15$ mM (Gill et al., 2007; Fig. 1). Sulfate levels may have declined 107 transiently after that time (Luo et al., 2010; Newton et al., 2011). For the most part, however, 108 fossils, biomarker molecules and molecular clocks place the rise of diatoms, coccolithophorids, 109 and photosynthetic dinoflagellates in late Paleozoic to early Mesozoic oceans, where [ $\mathrm{SO}_{4}{ }^{2-}$ ] lay 110 in the range of $13-27 \mathrm{mM}$. In today’s oceans, $\left[\mathrm{SO}_{4}{ }^{2-}\right]$ is $28 \mathrm{mM}$, at or near its historic maximum.

111 Of course, $\left[\mathrm{SO}_{4}{ }^{2-}\right]$ varies in space as well as in time, in the ocean, and not all aquatic

112 environments on Earth have $\left[\mathrm{SO}_{4}{ }^{2-}\right]$ as high as in the oceans. Freshwater environments have

$113\left[\mathrm{SO}_{4}{ }^{2-}\right]$ values of 0.01 to $1 \mathrm{mM}$ (Holmer \& Storkholm, 2001; Giordano et al., 2008).

\section{Sulfur use by algae}

116 How might changing sulfate availability affect phytoplankton growth? Sulfur is an essential 117 element for all organisms (Schultze et al., 1992; Marrs, 1996; Grossman \& Takahashi, 2001).

118 Algae acquire sulfur from the environment as $\mathrm{SO}_{4}{ }^{2-}$, and $\mathrm{SO}_{4}{ }^{2-}$ uptake is regulated by sulfate 119 availability itself (Yildiz et al., 1994; Pollock et al., 2005).

120 The sulfur assimilated by algae finds functional use in three main classes of biomolecule.

121 There is a universal requirement for sulfur in proteins. The S-bearing amino acid cysteine forms 122 disulfide bridges used to stabilize protein conformation, and a second S-bearing amino acid, 123 methionine, is the starting material for protein synthesis (Adams \& Capecchi, 1966, Webster et 124 al., 1966). There are indications that the abundance of S-amino acids can be modulated in 125 response to changes in environmental S availability (Giordano et al., 2000). Iron-sulfur clusters 126 and thiol groups lie at the heart of molecular function in many enzymes and electron transport 127 systems, and thiols also mediate the interaction of biomolecules with metals (Kawakami et al., 128 2006). Sulfur occurs, as well, in sulfolipids, found in membranes. Sulfolipids are obligate 129 constituents of the thylakoid membranes in chloroplasts (Goss \& Wilhelm 2009) and can, in 130 some instances, substitute facultatively for membrane phospholipids in P-limited environments 131 (Van Mooy et al., 2006). 
132

133

134

135

136

137

138

Sulfonium compounds are positively charged molecules in which a single sulfur atom is linked to three functional groups. Algae and higher plants synthesize a variety of sulfonium compounds, of which 3-dimethylsulfoniumproprionate, or DMSP (Keller et al., 1989; Ratti \& Giordano, 2008), is the best known. Many marine algae (and some halophytic angiosperms) produce DMSP; intracellular concentrations range from 50 to $400 \mathrm{mM}$, comprising a measurable proportion of all organic S in the cell (Matrai \& Keller, 1994; Keller et al., 1999; Wolfe, 2000; Yoch, 2002; Ratti \& Giordano, 2008).

Several functions have been attributed to DMSP. Inspired by the Gaia hypothesis, Charlson and colleagues (1987) suggested that DMS released to the atmosphere by DMSP catabolism governs a feedback mechanism between algal growth and global temperature (see also Andreae \& Crutzen, 1997). Other authors have focused attention on the role played by DMSP within the cell (Giordano et al., 2008; Ratti \& Giordano, 2008). DMSP has been proposed to act as an osmoprotectant (Stefels, 2000;Van Bergeijk et al., 2003), a cryoprotectant (Karsten et al., 1996; Rijssel \& Gieskes, 2002), an antioxidant (Sunda et al., 2002; Bucciarelli \& Sunda, 2003) and a molecular defense against grazing, thanks to the toxicity of acrylate produced during DMSP catabolism (Wolfe et al., 1997; Wolfe, 2000). There is also evidence that intracellular DMSP concentration increases under conditions of nitrogen depletion (Bucciarelli \& Sunda, 2003), perhaps because DMSP is a structural analogue of glycine betaine, an ammonium compound that acts as a compatible solute in many marine algae (Rhodes \& Hanson, 1993). Elemental composition has been assayed for relatively few algae (e.g. Ho et al., 2003; Quigg et al. 2003, 2011), but data in hand suggest that chlorophyll a+c algae have lower C:S than green algae and cyanobacteria (Norici et al., 2005). Why this should be so remains conjectural, although one study reported that the freshwater diatom Cyclotella meneghiniana contains significantly more sulfolipid than the freshwater green alga Chlamydomonas reinhardtii (Vieler et al., 2007). To the extent that lower C:S is a general feature of chlorophyll a+c algae (Goss \& Wilhelm, 2009), it provides a potential physiological link between Phanerozoic increase in marine sulfate concentrations and the evolutionary expansion of diatoms, coccolithophorids and dinoflagellates.

\section{MATERIALS AND METHODS}




\section{Cultures}

For our first experiment, on the impact of sulfate concentration per se, semi-continuous cultures of the cyanobacterium Synechococcus sp. (UTEX LB 2380), the green alga Tetraselmis suecica (PCC 305), the diatom Thalassiosira weissflogii (CCAP 1085/1), the coccolithophorid Emiliania huxleyi (PML 92/11), and the dinoflagellate Protoceratium reticulatum (PRA 0206) were grown axenically in $150 \mathrm{~mL}$ glass tubes $(19 \mathrm{~cm} \times 3.5 \mathrm{~cm})$ filled with $100 \mathrm{~mL}$ of ESAW (Enriched Seawater Artificial Medium; Berges et al., 2001) buffered with $10 \mathrm{mM}$ Tris-HCl, pH 8.0. Each species was cultured in the presence of $1 \mathrm{mM}, 5 \mathrm{mM}, 10 \mathrm{mM}, 20 \mathrm{mM}$ or $30 \mathrm{mM}$

$172 \mathrm{Na}_{2} \mathrm{SO}_{4}$ in order to mimic differing marine $\left[\mathrm{SO}_{4}{ }^{2-}\right]$ from the Proterozoic to the present. The 173 osmolarity of the medium was kept constant at $0.45 \mathrm{~mol} \mathrm{~L}^{-1}$ using $\mathrm{NaCl}$.

Cultures were maintained at $20^{\circ} \mathrm{C}$ under a continuous photon flux density (PFD) of 120 on cells in the exponential growth phase allowed to grow at the given $\mathrm{SO}_{4}{ }^{2-}$ concentration for at least 4 generations prior to any measurement.

For a second experiment, designed to assess the impact of grazers on the response to changes in sulfate concentrations, the ciliate Euplotes sp. was added to monospecific algal cultures in a proportion of about $0.05-0.1 \mu \mathrm{g}$ of algal C per ciliate cell. Growth conditions for these cultures were the same as for the first experiment. We were unable to grow E. huxleyi in the presence of ciliates, and so this species was omitted from subsequent experiments.

For a third set of experiments, phytoplankton species were grown in reconstructed paleoenvironments. Three media were used, all based on ESAW: one was designed to mimic the typical composition of today's ocean; another was intended to approximate conditions in earlier

186 Paleozoic oceans, and a third had a composition thought to mirror the composition of Proterozoic oceans. Sulfate levels in our Paleozoic and Proterozoic media are based on those shown in Figure 1 (see also Shen et al., 2002; Kah et al., 2004 for Proterozoic [ $\mathrm{SO}_{4}{ }^{2-}$ ]). Nitrogen, iron, and molybdenum values are based on estimates in Anbar and Knoll (2002), Saito et al. (2003),

190 Scott et al. (2008), and Canfield et al. (2008); while single values stand in for abundances 191 through long time intervals, the media we prepared faithfully reflect the view that nitrogen in 192 Proterozoic photic zones was predominantly ammonium, and both Fe and Mo levels were higher 193 than in younger oceans. $\mathrm{P}_{\mathrm{CO}_{2}}$ of the air in equilibrium with our Paleozoic medium was based on 
194 model estimates by Berner (e.g. Berner \& Kothvala, 2001); Proterozoic $\mathrm{P}_{\mathrm{CO} 2}$ was based on the

195 estimate by Kaufman \& Xiao (2003). Table 1 shows the ESAW modifications and $\mathrm{P}_{\mathrm{CO}_{2}}$ in

196 equilibrium with these media for each treatment. In these experiments, we grew monospecific

197 cultures of Synechococcus sp., Tetraselmis suecica, Thalassiosira weissflogii, and Protoceratium

198 reticulatum, as well as mixed cultures initially containing equal cell numbers of each species.

199 The mixed cultures were started from semicontinuous monospecific cultures, acclimated

200 to each growth regime for at least 4 generations. The cultures were diluted daily at the maximum

201 rate of the slowest growing species (P. reticulatum), to ensure that the selection of species was

202 not due to the fact that the slowest growing species were washed out. The cultures were

203 maintained for at least 15 days, prior to sampling; this time was determined to be sufficient for

204 the cultures to reach equilibrium (i.e. in all case no further change in relative cell abundance

205 occurred after this time; in fact, equilibration usually occurred after about 5-10 days).

\section{Growth rate, cell size and dry weight}

208 Cell concentrations of Synechococcus sp., T. weissflogii, T. suecica, and E. huxleyi were 209 estimated with a Burker hemocytometer, while the number of the larger $P$. reticulatum cells was 210 measured using a Sedgwick-Rafter chamber (McAlice, 1971). Specific growth rates, $\mu$, were

211 derived from daily counts of exponentially growing cells in batch cultures, carried out on a

212 minimum of three distinct cultures for each treatment. These growth rate were used to establish

213 the dilution rates of semicontinuous cultures.

214 The volume of T. weissflogii cells was calculated from microscope measurements of the

215 longitudinal and transverse axes of cells, using the equation $V=\pi d^{2} h / 4$ (Hillebrand et al., 1999).

216 T. suecica cell volume was calculated from measurements of the longitudinal and transverse axes

217 of the cells using the volume equation for a prolate spheroid $V=\pi d^{2} h / 6$ (Hillebrand et al.,

218 1999). E. huxleyi and P. reticulatum cell volumes were estimated from measurements of the

219 transverse axis, using the equation $V=\pi d^{3} / 6$ (Hillebrand et al., 1999). Measurements were

220 conducted on three different cultures; 60-100 cells were measured for each culture.

221 Synechococcus sp. cell volume was measured using a CASY TT cell counter (Innovatis AG, 222 Reutlingen, Germany). 
For dry weight determination, cells were washed with an ammonium formate solution

224 isosmotic to the culture media and dried at $100^{\circ} \mathrm{C}$ until weight stabilized. Measurements were 225 conducted for at least three independent cultures.

\section{Elemental Composition: $\mathrm{C}: \mathrm{N}: \mathrm{S}$ and $\mathrm{C}, \mathrm{N}, \mathrm{S}$ quotas}

Cellular abundances of $\mathrm{C}, \mathrm{N}$ and $\mathrm{S}$ were determined using an elemental analyzer (EA1108, Carlo Erba Instruments, Milan, Italy) on 1-6 mg of cells (dry weight) washed twice with an ammonium formate solution isosmotic to the culturing media and dried at $80^{\circ} \mathrm{C}$ until the weight stabilized. To facilitate combustion in the reactor of the elelmental analyzer, a small amount of vanadium peroxide was added to each sample. Sulphanilamide (C:N:S=6:2:1) was used as a standard. Elemental quotas were calculated as pico- or femto-grams per cell, normalized to cell dry weight and to cell volume. The oven temperature was set $1020^{\circ} \mathrm{C}$, , the column temperature at $70^{\circ} \mathrm{C}$, and the detector temperature at $190^{\circ} \mathrm{C}$. The He flow was $100 \mathrm{~mL}$ $\mathrm{min}^{-1}$; the reference He flow was $40 \mathrm{~mL} \mathrm{~min}^{-1}$; and the $\mathrm{O}_{2}$ flow was $20 \mathrm{~mL} \mathrm{~min}^{-1}$. Data acquisition and analysis were performed with the software EAS-Clarity (DataApex Ltd. 2006, Czech Republic). All measurements were repeated for four independent cultures.

\section{DMSP measurement}

A relationship between C:S and DMSP has been proposed (Norici et al., 2005; Takahashi et al., 2011). We therefore measured DMSP in all growth regimes to asses if such relationship

243 existed. Cells were filtered on glass fiber filters (GF/F; Whatman, Maidstone, England) and

244 transferred into $12 \mathrm{~mL}$ glass vials; $6 \mathrm{~mL}$ of ice cold $5 \mathrm{~N} \mathrm{NaOH}$ were added, and the vials were

245 quickly closed using screw caps with rubber septa. Samples were incubated overnight in the 246 dark, at $4{ }^{\circ} \mathrm{C}$ (Steinke et al. 1998). DMS generated by the alkaline hydrolysis of DMSP was 247 measured with a modification of the method described by van Bergeijk and Stal (1996). A 25

$248 \mu \mathrm{L}$ gas aliquot was taken from the headspace of the vials using a gas-tight syringe and injected 249 into a gas chromatograph (Focus, Thermo Fisher Scientific, Waltham, MA, USA) equipped with 250 a capillary column made of a polystyrene-divinylbenzene copolymer (RT-Q PLOT; 0.53 mm; 30 251 m, Restek, PA, USA) and a flame ionization detector (FID). The retention time of DMS was $252 \sim 4.7$ minutes. DMSP standards (Research Plus Inc, Barnegat, NJ, USA) were treated as the 253 samples and used for calibration. Spectra were acquired and elaborated using the Chrom-Card 
254 Software (Thermo Fischer Scientific, Waltham, MA, USA), with measurements repeated for at 255 least three independent cultures.

\section{Chlorophyll Fluorescence}

The chlorophyll fluorescence associated to PSII was determined to obtain a general indication of the health conditions of the algae and of the functional status of their photosynthetic apparatus, under the various growth regimes. For these measurements, we used a Dual-PAM100 fluorometer provided with an optical unit ED-101US/MD for suspensions (Walz GmbH,

262 Effeltrich, Germany; Quigg et al., 2006). Cells were collected by filtration (P. reticulatum) or

263 centrifugation (T. suecica, T. weissflogii, Synechococcus sp. and E. huxleyi), washed and

264 resuspended in fresh medium. The samples were dark adapted for $15 \mathrm{~min}$, an interval previously

265 determined to be sufficient for complete oxidation of the electron transport chain. A $1.5 \mathrm{~mL}$

266 aliquot of cell suspension was used for the measurement. The measuring beam was supplied at

267 an irradiance of $24 \mu \mathrm{mol}$ photons $\mathrm{m}^{-2} \mathrm{~s}^{-1}$ and a frequency of $20 \mathrm{KHz}$. The saturating pulse had an

268 intensity of $10,000 \mu \mathrm{mol}$ photons $\mathrm{m}^{-2} \mathrm{~s}^{-1}$ and a duration of $300 \mathrm{~ms}$. The actinic light was provided

269 at a photon flux density similar to that used for growth $\left(126 \mu \mathrm{mol}\right.$ photons $\left.\mathrm{m}^{-2} \mathrm{~s}^{-1}\right)$. The

270 maximum fluorescence yield and the dark fluorescence yield of dark adapted (Fm and Fo,

271 respectively) and illuminated (Fm'and Fo') cells were determined. The maximal quantum yield

272 of PSII and the quenching parameters qP, qL, qN and NPQ were derived from these

273 measurements according to Schreiber et al. (1986) and Kramer et al. (2004). Data acquisition

274 and analysis were conducted using the Dual-PAM v1.8 software (Walz GmbH, Effeltrich,

275 Germany).

\section{Statistics}

278 Data are reported as mean \pm standard deviation for measurements obtained from at least 279 three distinct cultures. Statistical significance of differences among the means was determined

280 by analysis of variance (ANOVA) and Tukey’s post-hoc test, using GraphPad Prism 4.03

281 software (GraphPad Software, San Diego, CA, USA), with the level of significance set at 95\%. 


\section{Experiment 1: Sulfate availability and microalgal growth}

In our initial experiment, we simply varied the amount of sulfate in growth media, holding other environmental parameters constant. Our $1 \mathrm{mM}$ to $5 \mathrm{mM}\left[\mathrm{SO}_{4}{ }^{2-}\right]$ treatments probably bracket levels actually experienced by early cyanobacteria and green algae radiating in Neoproterozoic and earlier Paleozoic oceans; whereas the $10 \mathrm{mM}$ to $20 \mathrm{mM}$ [SO${ }_{4}{ }^{2-}$ ] levels approximate sulfate abundances in the late Paleozoic and Mesozoic oceans that supported early dinoflagellates, coccolithophorids and diatoms (Fig. 1). Many physiological parameters show no statistically significant variation with changing $\left[\mathrm{SO}_{4}{ }^{2-}\right.$; ; these data are reported as Supplementary Information. One parameter that does show significant variation is specific growth rate $(\mu=$ proportional increase in biomass per day during exponential growth phase). Barton et al. (2010) argue that high growth rate is the most appropriate measure of organismic fitness in phytoplankton. Certainly, differential growth rate is a property we need to track in experimental tests of evolutionary hypotheses.

Neither the cyanobacterium, Synechococcus sp., nor the green alga, Tetraselmis suecica, showed any consistent response to increasing sulfate availability (Fig. 2). In contrast, the specific growth rates of all three chlorophyll a+c algae increased with increasing sulfate availability, two of them (the dinoflagellate Protoceratium reticulatum and the coccolithophorid Emiliania huxleyi) significantly (Fig. 2). Our chlorophyll a+c species all grew most slowly in the $1 \mathrm{mM}$ sulfate treatment; indeed, Protoceratium reticulatum did not grow at all. All showed improved growth at $5 \mathrm{mM}$, and two, P. reticulatum and E. huxleyi, grew faster still at $10 \mathrm{mM}$. No increase in growth rate was observed at sulfate abundances above $10 \mathrm{mM}$. Thus, these species showed increased growth up to the sulfate levels experienced by their early ancestors, but not beyond that level. Consistent with these results, non-photochemical quenching, a physiological measure of stress (sensu lato), is most pronounced in the chlorophyll a+c species grown at low $\left[\mathrm{SO}_{4}{ }^{2-}\right]$ (see Supplementary Information).

312 show no variation in C:S with increasing sulfate abundance, whereas the three chlorophyll $\mathrm{a}+\mathrm{c}$ 313 algae (especially P. reticulatum) do (Fig. 3). Increased S content does not relate to increasing 314 DMSP, as DMSP:S quota did not vary with $\left[\mathrm{SO}_{4}{ }^{2-}\right]$ in any of the three species that produced this 
315 compound (Fig. 3; the diatom Thalassiosira weissflogii did not produce DMSP). C:N also

316 shows no strong relationship with $\left[\mathrm{SO}_{4}{ }^{2-}\right]$ (Fig. 3).

\section{Experiment 2: Sulfate availability and microalgal growth in the presence of a grazer}

In actual oceans, predation can exert a strong influence on net growth rates. To examine whether the growth relationships observed in our first experiment are robust when grazers are present, we ran the experiment again, but with a ciliate, Euplotes sp., present. Our dinoflagellate, $P$. reticulatum, formed a protective cyst upon introduction of the ciliate predator and so was not considered further. Also, rates of predation on E. huxleyi outstripped growth rate, in time eliminating the algal population. Thus, we were only able to compare our cyanobacterium, green alga and diatom across the full spectrum of sulfate abundances (Fig. 4). For T. suecica and T. weissflogii, specific growth rate increased for all treatments when Euplotes sp. was present. In this experiment, however, $T$. suecica did show differences in growth rate at different $\left[\mathrm{SO}_{4}{ }^{2-}\right]$, whereas T. weissflogii did not. Specifically, when grown in the presence of Euplotes sp., T. suecica showed no increase in specific growth rate relative to pure culture at $1 \mathrm{mM}\left[\mathrm{SO}_{4}{ }^{2-}\right]$, but did at higher sulfate concentrations. An opposite result was observed in Synechococcus sp.; when the cyanobacterium was cultured in the presence of grazers the specific growth rate was not affected (at $5 \mathrm{mM}$ or $30 \mathrm{mM}\left[\mathrm{SO}_{4}{ }^{2-}\right]$ ) or decreased significantly (1 mM, $10 \mathrm{mM}$ and $30 \mathrm{mM}$ $\left[\mathrm{SO}_{4}{ }^{2-}\right]$; Fig 4). Except at the lowest sulfate level, T. suecica grown with the ciliate had a C quota (amount of carbon per cell) about twice that of cells grown in pure culture (Fig. 3). As cell volume is unchanged in these treatments (Supplementary Information), the amount of organic material per cell must be higher in cells subject to grazing. C:S did not vary among treatments for our experimental green alga (Fig. 3), suggesting a relatively tight linkage between $\mathrm{C}$ and $\mathrm{S}$ uptake. Perhaps sulfate limitation at $1 \mathrm{mM}\left[\mathrm{SO}_{4}{ }^{2-}\right.$ ] prevents the physiological response observed in other treatments with predators present. Our diatom species shows no similar response at low

$342\left[\mathrm{SO}_{4}{ }^{2-}\right]$. The presence of Euplotes sp. in the Synechococcus sp. culture resulted in a decrease in $343 \mathrm{C}: \mathrm{N}$ at lower $\left[\mathrm{SO}_{4}{ }^{2-}\right](1 \mathrm{mM}, 5 \mathrm{mM}$ and $10 \mathrm{mM})$ and a decrease of about $50 \%$ in $\mathrm{C}: \mathrm{S}$ at all $344\left[\mathrm{SO}_{4}{ }^{2-}\right]$. 
Experiment 3: Sulfate availability and microalgal growth when multiple environmental parameters are allowed to vary.

While experiments on axenic cultures of single species identify changes in growth rate with changing $\left[\mathrm{SO}_{4}{ }^{2-}\right]$, they do not directly measure competitive ability. For this reason, we completed a third set of experiments, asking how our experimental species fare when grown together. Under culture conditions designed to emulate present day seawater (“modern” in Table 1 and Figs. 5 and 6), our diatom species not only had the highest growth rates in axenic culture, but also the highest growth rate in mixed culture, identifying it as the best competitor under the specified culture conditions.

A complicating issue is that sulfate was not the only environmental variable to change systematically through Earth history. The availability of trace metal micronutrients has changed as a function of marine redox state (Anbar \& Knoll, 2002; Saito et al., 2003), and $\mathrm{P}_{\mathrm{CO} 2}$ has decreased through time (albeit not monotonically) as well (Berner \& Kothavala, 2001). Thus, in our third set of experiments we grew photosynthetic microorganisms in a series of culture conditions designed to mimic chemical environments in Proterozoic, Paleozoic and modern oceans. As shown in Table 1, our Paleozoic treatment differs from present day conditions in having lower sulfate $(14 \mathrm{mM})$ and higher $\mathrm{P}_{\mathrm{CO} 2}(2500 \mathrm{ppm})$; the Proterozoic treatment has still lower sulfate (3 mM), higher $\mathrm{P}_{\mathrm{CO} 2}(5000 \mathrm{ppm})$, lower metal concentrations, and ammonia rather than nitrate as the source of nitrogen.

Most species exhibited higher growth rates under the two "ancient” seawater conditions, although not always significantly so (Fig. 5). T. weissflogii doubled its specific growth rate in the Proterozoic treatment, perhaps as a function of iron availability. Growth of P. reticulatum scaled with $\mathrm{P}_{\mathrm{CO} 2}$. Only the cyanobacterium Synechococcus sp. did not show monotonic increases in growth with successively “older” treatments. For reasons we cannot explain, Synechococcus sp. grew most poorly under Paleozoic conditions. Note that relative specific

372 growth rates observed in the present day treatment of this experiment are consistent with those 373 found in the $30 \mathrm{mM}\left[\mathrm{SO}_{4}{ }^{2-}\right]$ treatment in experiment 1.

We observed a number of responses when the species were grown in mixed rather than

375 pure culture. T. suecica showed the same pattern of differential growth among treatments as in the pure culture experiment, but at lower absolute specific growth rates. In mixed culture 
Synechococcus sp. grew more slowly in the present day treatment than its growth in pure culture would have predicted; this may be a direct response to the growth of $T$. weissflogii, which showed a much higher growth rate in mixed culture than would be predicted from the pure culture experiments. Evidently, T. weissflogii is a superior competitor in our modern seawater experiment. P. reticulatum did not grow at all in the mixed cultures.

Whereas our diatom grew faster than other species in the mixed culture experiment in modern seawater, consistent with diatom prominence in present day primary production, our green alga outgrew the other taxa in Paleozoic seawater. Our cyanobacterium grew best in Proterozoic seawater, but, as in all other treatments, grew more slowly than the two algal species in the mixed culture.

\section{DISCUSSION}

Our experiments were designed to test an evolutionary hypothesis inspired by an observed stratigraphic correlation between seawater chemistry and phytoplankton composition through earth history. Existing data on the chemical composition of phytoplankton cells indicate that green algae and cyanobacteria, dominant primary producers in Proterozoic and Paleozoic shelf waters, have higher $\mathrm{C}: \mathrm{S}$ than diatoms, dinoflagellates, and coccolithophores, dominant shelf phytoplankton since the later Mesozoic Era. As more species are analyzed, this distinction may turn out to be statistical rather than absolute, but then the fossil record is a statistical digest of phytoplankton composition through time. The changing taxonomic composition of the phytoplankton parallels long terms changes in the abundance of sulphate in seawater, motivating the hypothesis that increasing $\left[\mathrm{SO}_{4}{ }^{2-}\right]$ might have facilitated the expansion of algae with relatively low C:S. The only way to test this or any other hypothesis relating evolution and environmental change is by physiological experiment (see Zerkle et al., 2006, and Glass et al., 2009, for pioneering examples).

In our initial experiment, our dinoflagellate and coccolithophorid species grew poorly at the low sulphate concentrations likely to have characterized Proterozoic and early Paleozoic oceans, but showed a significant increase in growth rate at sulphate levels thought to have been reached only in late Paleozoic and younger oceans. Our experimental diatom also showed 
408 increased growth at higher $\left[\mathrm{SO}_{4}{ }^{2-}\right]$, but not with statistical significance. In contrast, our green 409 and cyanobacterial species showed no directional growth response to increasing [ $\mathrm{SO}_{4}{ }^{2-}$ ].

410 These results are consistent with the sulphate facilitation hypothesis, but they do not rule 411 out other influences. For example, the observation that $T$. weissflogii grew more rapidly than $T$. 412 suecica in all treatments is consistent, as well, with Kooistra and collegues'(2007) view that 413 diatom success owes much to clade-specific adaptations. Differences among experimental 414 organisms in growth at very low $\left[\mathrm{SO}_{4}{ }^{2-}\right.$ ] also correlate with the relative success of different 415 photosynthetic clades in freshwater. Most green algal and cyanobacterial species live in lakes, 416 rivers or soils, as do nearly half of diatom species, but only a small proportion of dinoflagellates 417 and no coccolithophorids (Falkowski et al., 2004).

418 Our second experiment, in which a predator was introduced to algal cultures, 419 demonstrates that growth responses to changes in the physical environment can be modified by 420 changes in biological environment. The relative specific growth rates between our green alga 421 and diatom species grown at differing $\left[\mathrm{SO}_{4}{ }^{2-}\right]$ were retained in experiment 2 , but within species 422 responses to sulfate availability were not. In continuing experiments we hope to pursue this 423 further, including experimental treatments that add metazoan micrograzers such as copepods. 424 In our third set of experiments, when the experimental algae were grown individually 425 under culture conditions designed to simulate modern, Paleozoic and Proterozoic seawater, all 426 species exhibited higher growth rates under more “ancient” conditions, perhaps reflecting the 427 fertilizing effects of elevated iron and $\mathrm{CO}_{2}$. When species were grown in mixed culture, the 428 species that grew best in the modern and paleozoic treatments were those that were most 429 prominent in the modern and Paleozoic records - diatoms for the present day and green algae for 430 the Paleozoic Era. Thus, our experimental results are all consistent with the hypothesis that 431 increasing sulfate played a role in the large scale pattern of phytoplankton succession observed in 432 the geologic record. Moreover, they are consistent with the additional observation that green 433 algae were unusually prominent phytoplankton components during the two Mesozoic intervals 434 when sulphate levels are thought to have declined transiently to low levels (Payne \& van de 435 Schootbrugge, 2007; Luo et al., 2010; Newton et al., 2011).

436 That stated, when taken as a whole, our experiments caution against simplistic 437 interpretation of these results. Through geologic time, as $\left[\mathrm{SO}_{4}{ }^{2-}\right]$ increased, $\mathrm{P}_{\mathrm{CO} 2}$ decreased, and 438 so did the abundance of redox sensitive metals such as Fe. Thus, decreasing iron availability 
439 might have had the evolutionary consequences postulated by Quigg et al. (2003), although

440 physiological effects of changing Fe on phytoplankton growth and competitive ability have yet

441 to be tested directly by experiments. (Our results in experiment 3 show that the diatom, $T$.

442 weissflogii, actually grew best in the iron-rich Proterozoic medium, suggesting that the Fe

443 hypotheses might usefully be restated to postulate that chlorophyll a+c algae grow less poorly

444 than greens when iron is scarce). Our results also suggest that grazing affects growth rates under

445 different nutrient conditions and does so differently for different taxa. Calanoid copepods and

446 other pelagic planktivores have a scant fossil record (Selden et al., 2010), but may well have

447 invaded the pelagic realm on time scales relevant to the rise of armored chlorophyll a+c

448 phytoplankton (Bradford-Grieve, 2002). Finally, the relatively high growth rates achieved by

449 our diatom species over a wide range of culture conditions are consistent with Kooistra et al.

450 (2007) hypothesis that adaptations specific to diatoms explain their extraordinary ecological and 451 evolutionary radiation.

\section{CONCLUSIONS}

The experiments described in this paper provide but a first step toward understanding the 456 influence of changing marine environments on phytoplankton evolution through time. Further 457 experiments are necessary to show to what extent the species we have chosen are representative 458 of larger clades. Nonetheless, the results permit some first order tests of our motivating 459 hypothesis.

460 While more experiments need to be run, it is not too early to suggest that existing 461 hypotheses to explain the geologic succession of primary producers in the oceans are not so 462 much wrong as incomplete. The rise of chlorophyll a+c phytoplankton may not reflect the 463 influence of sulfate availability vs. Fe availability vs. increasing predation pressure vs. individual 464 adaptations so much as the synergistic influences of multiple physical and biological factors that 465 have covaried through time. Secular variation in sulfate abundance will play a role in continuing 466 explanations, but not to the exclusion of other influences. 
470 Funding information omitted in agreement with the anonymity policy of Geobiology - included 471 in file submitted "not for review”. We thank Professor Ruediger Hell, Heidelberg University, for 472 his help in the determination of sulfate uptake rates, Ben Gill for discussion of sulfate in ancient 473 oceans, and Peter Girguis for comments on a draft manuscript, and three reviewers for 474 constructive criticisms that improved our paper.

475

476 


\section{REFERENCES}

Adams JM, Capecchi MR (1966) N-formylmethionyl-sRNA as the initiator of protein synthesis. Proceedings of the National Academy of Sciences, USA 55, 147-155.

Anbar AD, Knoll AH (2002) Proterozoic ocean chemistry and evolution: a bioorganic bridge?

Andreae MO, Crutzen PJ (1997) Atmospheric Aerosols: biogeochemical sources and role in atmospheric chemistry. Science 276, 1052-1058.

Barton AD, Dutkiewicz S, Flierl G, Bragg J Follows MJ (2010) Patterns of diversity in marine phytoplankton. Science 327, 1509-1511.

Berges JA, Franklin DJ, Harrison PJ (2001) Evolution of an artificial seawater medium: improvements in enriched seawater, artificial water over the last two decades. Journal of Phycology 37, 1138-1145.

Berner RA, Kothavala Z (2001) GEOCARB III: A revised model of atmospheric $\mathrm{CO}_{2}$ over Phanerozoic time. American Journal of Science 301, 182-204.

Bowler C, Vardi A, Allen AE (2010) Oceanographic and biogeochemical insights from diatom genomes. Annual Review of Marine Science 2, 333-365.

Bown PR, Lees JA, Young JR (2004) Calcareous nannoplanton evolution and diversity through time. In: Coccolithophores: From Molecular Processes to Global Impact (eds. Thierstein HR and Young JR). Springer-Verlag, Berlin, pp. 481-505.

Bradford-Grieve JM (2002) Colonization of the pelagic realm by calanoid copepods. Hydrobiologia 485, 223-244. 
Bucciarelli E, Sunda WG (2003) Influence of $\mathrm{CO}_{2}$, nitrate, phosphate and silicate limitation on intracellular dimethylsulfonioproprionate in batch cultures of coastal diatom Thalassiosira pseudonana. Limnology and Oceanography 48, 2256-2265.

Canfield DE (2004) The evolution of the Earth surface sulfur reservoir. American Journal of Science 304, 839-861.

Canfield DE, Habicht KS, Thamdrup B (2000) The Archean sulfur cycle and the early history of atmospheric oxygen. Science 288, 658-661.

Canfield DE, Poulton SW, Knoll AH, Narbonne GM, Ross G, Goldberg T, Strauss H (2008) Ferruginous conditions dominated later Neoproteozoic deep water chemistry. Science 321, 949-952.

Charlson RJ, Lovelock JE, Andreae MO, Warren SG (1987) Oceanic phytoplankton atmospheric sulfur, cloud albedo and climate. Nature 326, 655-661.

Falkowski P, Knoll AH (2007) The Evolution of Primary Producers in the Sea. Elsevier, Burlington, pp. 207-249.

Falkowski PG, Katz ME, Knoll AH, Quigg A, Raven JA, Schofield O, Taylor FJR (2004) The evolution of modern eukaryotic phytoplankton. Science 305, 354-360.

Gill BC, Lyons TW, Saltzman MR (2007) Parallel, high-resolution carbon and sulfur isotope records of the evolving Paleozoic marine sulfur reservoir. Palaeogeography Palaeoclimatology Palaeoecology 256, 156-173.

Gill BC, Lyons TW, Young S, Kump L, Knoll AH, Saltzman MR (2011) Geochemical evidence for widespread euxinia in the Later Cambrian ocean. Nature 469, 80-83. 
537 Giordano M, Norici A, Ratti S, Raven JA (2008) Role of sulfur for phytoplankton (bacterial phototrophs and algae): acquisition, metabolism and ecology. In: Sulfur Metabolism in Phototrophic Organisms, Advances in Photosynthesis and Respiration 27 (eds Hell R, Dahl C, Knaff D, Leustek T). Elsevier, Amsterdam, pp. 405-423.

Giordano M, Pezzoni V, Hell R (2000) Strategies for the allocation of resources under sulfur limitation in the green alga Dunaliella salina. Plant Physiology 124, 857-864.

Glass JB, Wolfe-Simon F, Anbar AD (2009) Coevolution of metal availability and nitrogen assimilation in cyanobacteria and algae. Geobiology 7, 100-123.

Goss R, Wilhelm C (2009) Lipids in algae, lichens and mosses, In: Lipids in photosynthesis: essential and regulatory functions. Advances in Photosynthesis and Respiration Volume 30 (eds Murata N, Wada H). Springer, The Netherlands, pp. 117-137.

Grossman A, Takahashi H (2001) Macronutrient utilization by photosynthetic eukaryotes and the fabric of interactions. Annual Review of Plant Physiology and Plant Molecular Biology

Habicht KS, Gade M, Thamdrup B, Berg P. Canfield DE (2002) Calibration of sulfate levels in the Archean ocean. Science 298, 2372-2374.

Harwood DM, Chang KH, Nikolaev VA (2004) Late Jurassic to earliest Cretaceous diatoms 52, 163-210. from Jasong Synthem, Southern Korea: evidence for a terrestrial origin. In: Abstracts, $18^{\text {th }}$ International Diatom Symposium, Miedzyzdroje, Poland (eds Witkowski A, for pelagic and benthic microalgae. Journal of Phycology 35, 403-424. 
Ho T-Y, Quigg A, Finkel ZC, Milligan AJ, Wyman K, Falkowski PG, Morel FMM (2003) The elemental composition of some marine phytoplankton. Journal of Phycology 39, 11451159.

Holmer M, Storkholm P (2001) Sulfate reduction and sulfur cycling in lake sediments: a review. Freshwater Biology 46, 431-451.

Horita J, Zimmermann H, Holland HD (2002) Chemical evolution of seawater during the Phanerozoic: Implications from the record of marine evaporites. Geochimica et Cosmochimica Acta 66, 3733-3756.

Johnston, DT, Wolfe-Simon F, Pearson A, Knoll AH (2009) Anoxygenic photosynthesis modulated Proterozoic oxygen and sustained Earth’s middle age. Proceedings of the National Academy of Sciences, USA 106, 16925-16929.

Kah LC, Lyons TW, Frank TD (2004) Low marine sulfate and protracted oxygenation of the Proterozoic biosphere. Nature 431, 834-838.

Karsten U, Kuck K, Vogt C, Kirst GO (1996) Dimethylsulfonioproprionate production in phototrophic organisms and its physiological function as a cryoprotectant. In: Biological and environmental chemistry of DMSP and related sulfonium compounds (eds Kiene RP, Visscher PT, Keller MD, Kirst GO). Plenum Press, New York, pp. 143-153.

Kaufman AJ, Xiao S (2003) High $\mathrm{CO}_{2}$ levels in the Proterozoic atmosphere estimated from analyses of individual microfossils. Nature, 425: 279-281.

Kawakami SK, Gledhill M, Achterberg EP (2006) Production of phytochelatins and glutathione by marine phytoplankton in response to metal stress. Journal of Phycology 42, 979-989.

Keller MD, Bellows WK, Guillard RRL (1989) Dimethyl sulfide production in marine phytoplankton. In: Biogenic sulfur in the environment (eds Saltzman ES, Cooper WJ). 
American Chemistry Society Symposium Series Volume 393, Washington DC, pp. 167182.

Keller MD, Kiene RP, Matrai PA, Bellows WK (1999) Production of glycine betaine and dimethylsulfonioproprionate in marine phytoplankton. I. Batch cultures. Marine Biology 135, 237-248.

Knoll AH, Summons RE, Waldbauer J, Zumberge J (2007) The geological succession of primary producers in the oceans. In: The Evolution of Primary Producers in the Sea (eds Falkowski P, Knoll AH). Elsevier, Burlington, pp. 133-163.

Kodner RB, Summons RE, Pearson A, Knoll AH (2008) Sterols in red and green algae: quantification, phylogeny and relevance for the interpretation of geologic steranes. Geobiology 6, 411-420.

Kooistra WHCF, Gersonde R, Medlin LK, Mann DG (2007) The origin and evolution of the diatoms: their adaptation to a planktonic existence. In: The Evolution of Primary Producers in the Sea (eds Falkowski P, Knoll AH). Elsevier, Burlington, pp. 207-249.

Kramer DM, Johnson G, Kiirats O, Edwards GE (2004) New fluorescence parameters for the determination of $\mathrm{Q}_{\mathrm{A}}$ redox state and excitation energy fluxes. Photosynthesis Research 79, 209-218.

Luo GM, Kump LR, Wang YB, Tong JN, Arthur MA, Yang H, Huang JH, Yin HF, Xie SC (2010) Isotopic evidence for an anomalously low oceanic sulfate concentration following end-Permian mass extinction. Earth and Planetary Science Letters 300, 101-111.

Marrs KA (1996) The function and regulation of glutathione S-transferares in plants. Annual Review of Plant Physiology 47, 127-158. 
629 Matrai PA, Keller MD (1994) Total organic sulfur and dimethylsulfonioproprionate in marine phytoplankton: intracellular variation. Marine Biology 119, 61-68.

McAlice BJ (1971) Phytoplankton sampling with the Sedgwick-Rafter cell. Limnology and

Moldowan JM, Talyzina NM (1998) Biogeochemical evidence for dinoflagellate ancestors in the early Cambrian. Science 281, 1168-1170. Oceanography 16,19-28.

Newton RJ, Reeves EP, Kafousia N, Wignall PB, Bottrell S, Sha J-G (2011) Low marine sulfate concentrations and the isolation of the European epicontinental sea during the Early Jurassic. Geology 39, 7-10.

Petrychenko OY, Peryt TM,T, Chechel EI (2005) Early Cambrian seawater chemistry from fluid inclusions in halite from Siberian evaporites. Chemical Geology 219, 149-161.

Pollock SV, Pootakham W, Shibagaki N, Moseley JL, Grossman AR (2005) Insights into the acclimation of Chlamydomonas reinhardtii to sulfur deprivation. Photosynthesis Research 86, 475-489. Falkowski PG (2003) The evolutionary inheritance of elemental stoichiometry in marine phytoplankton. Nature 425: 291-294. 
660 Quigg A, Irwin AJ, Finkel ZV (2011) Evolutionary inheritance of elemental stoichiometry in phytoplankton. Proceedings of the Royal Society B 278, 526-534.

662

Quigg A, Kevekordes K, Raven JA, Beardall J (2006) Limitations on microalgal growth at very low photon fluence rates: the role of energy slippage. Photosynthesis Research 88, 299310.

666

Ratti S, Giordano M (2008) Allocation of sulfur to sulfonium compounds in microalgae. In Sulfur Assimilation and Abiotic Stress in Plants (eds Khan NA, Singh S, Umar S). Springer-Verlag, Berlin, pp. 317-333.

Rhodes D, Hanson AD (1993) Quaternary ammonium and tertiary sulfonium compounds in higher plants. Annual Review of Plant Physiology and Plant Molecular Biology 44, 357384.

Rijssel M, Gieskes WWC (2002) Temperature, light, and the dimethylsulfnioproprionate (DMSP) content of Emiliania huxleyi (Prymnesiophyceae). Journal of Sea Research 48,

Schreiber U, Schliwa U, Bilger W (1986) Continuous recording of photochemical and nonphotochemical chlorophyll fluorescence quenching with a new type of modulation fluorometer. Photosynthesis Research 10, 51-62.

Schultze M, Quiclet-Sire B, Kondorosi E, Virelizer H, Glushka JN, Endre G, Gero SD, 688 Kondorosi A (1992) Rhizobium melitoti produces a family of sulphated lipooligosaccharides exhibiting different degrees of plant host specificity. Proceedings of the National Academy of Sciences of the USA 89, 192-196. 
692 Scott C, Lyons TW, Bekker A, Shen Y, Poulton SW, Chu X, Anbar AD (2008) Tracing the stepwise oxygenation of the Proterozoic ocean. Nature 452, 456-459.

Selden PA, Huys R, Stephenson MH, Heward AP, Taylor PN (2010) Crustaceans from bitumen clast in Carboniferous glacial diamictite extend fossil record of copepods. Nature

Shen Y, Canfield DE, Knoll AH (2002) Middle Proterozoic ocean chemistry: Evidence from the

Shen Y, Knoll AH, Walter MR (2003) Evidence for low sulfate and anoxia in a mid-Proterozoic marine basin. Nature 423, 632-635.

Stefels J (2000) Physiological aspects of the production and conversion of DMSP in marine algae and higher plants. Journal of Sea Research 43, 183-197.

Steinke M, Wolfe GV, Kirst GO (1998) Partial characterization of dimethylsulfonioproprionate

713 Summons RE, Walter MR (1990) Molecular fossils and microfossils of prokaryotes and protists from Proterozoic sediments. American Journal of Science 290, 212-244.

716 Sunda W, Kieber DJ, Kiene RP, Huntsman S (2002) An antioxidant function for DMSP and DMS in marine algae. Nature 418, 317-320.

Takahashi H., Kopriva S., Giordano M., Saito K., Hell R. (2011). Sulfur assimilation in 720 photosynthetic organisms: molecular functions and regulations of transporters and 
assimilatory enzymes. Annual Review of Plant Biology 62, in press; doi:

Van Bergeijk SA, Van der Zee C, Stal LJ (2003) Uptake and excretion of dimethylsulfoniopropionate is driven by salinity changes in marine benthic diatom Cylindrotheca closterium. European Journal of Phycology 3, 341-349.

Van Mooy BAS, Rocap G, Fredricks HF, Evans CT, Devol AH (2006) Sulfolipids dramatically decrease phosphorus demand in oligotrophic marine environments. Proceedings of the National Academy of Sciences, USA 103, 8607-8612.

Vermeij GJ (1977) The Mesozoic marine revolution: evidence from snails, predators and grazers. Paleobiology 3, 245-258.

Vieler A, Wilhelm C, Goss R, Süß R, Schiller J (2007) The lipid composition of the unicellular green alga Chlamydomonas reinhardtii and the diatom Cyclotella meneghiniana investigated by MALDI-TOF MS and TLC. Chemistry and Physics of Lipids 150, 14355. 
751 Wolfe GV (2000) The chemical defence ecology of marine unicellular plankton: constraints, 752 mechanisms, and impacts. The Biological Bulletin 198, 225-244.

753

754 Wolfe GV (2000) The chemical defence ecology of marine unicellular plankton: constraints, 755 mechanisms, and impacts. Biological Bulletin 198, 225-244.

756

757 Wolfe GV, Steinke M, Kirst GO (1997) Grazing-activated chemical defence in a unicellular 758 marine alga. Nature 387, 894-897.

759

760 Yildiz FH, Davies JP, Grossman AR (1994) The regulation of photosynthetic electron transport 761 in Chlamydomonas reinhardtii during sulfur-limited and sulfur-sufficient growth. Plant Physiology 104, 981-987.

763

764 Yoch DC (2002) Dimethylsulfonioproprionate: its source, role in the marine food web, and 765 biological degradation to dimethylsulfide. Applied and Environmental Microbiology 68, 5804-5815.

768 Zerkle AL, House CH, Cox RP, Canfield DE (2006) Metal limitation of cyanobacterial N-2 fixation and implications for the Precambrian nitrogen cycle. Geobiology 4, 285-297 


\section{FIGURE LEGENDS:}

Figure 1. Sulfate concentration and different taxa phytoplankton radiation over geological time. Paleobiologic data from Falkowski et al. (2004); data on sulphate abundances from Gill et al. (2007, 2011), Warren (2010), and sources therein.

Figure 2. Specific growth rate of $T$. suecica, $T$. weissflogii, $P$. reticulatum, and E. huxleyi cells acclimated to $1 \mathrm{mM}, 5 \mathrm{mM}, 10 \mathrm{mM}, 20 \mathrm{mM}$ or $30 \mathrm{mM}\left[\mathrm{SO}_{4}{ }^{2-}\right.$. Error bars indicate standard deviations about the mean $(\mathrm{n} \geq 3)$.

Figure 3. Panel A: C:N ratio in T. suecica, T. weissflogii, Synechococcus sp., P. reticulatum, and E. huxleyi cells cultured in the presence of five different sulfate concentrations. Panel B: C:N ratio in T. suecica, $T$. weissflogii and Synechococcus sp. cells cultured in the presence of five different sulfate concentrations and the ciliate predator Euplotes sp. Panel C: C:S ratio in T. suecica, T. weissflogii, Synechococcus sp., P. reticulatum, E. huxleyi cells acclimated to five different sulfate concentrations. Panel D: C:S ratio in T. suecica, T. weissflogii and Synechococcus sp. cells acclimated to five different sulfate concentrations and to the presence of Euplotes sp. Panel E: Ratio of DMSP cell content to cell S quota in T. suecica, T. weissflogii, P. reticulatum, and E. huxleyi cells acclimated to five different sulfate concentrations. Panel F: DMSP cell content;cell S quota in T. suecica cells acclimated to five different sulfate concentrations in the presence of Euplotes sp. Error bars indicate standard deviation about the mean $(n \geq 3)$.

Figure 4. Effect of the presence of Euplotes sp. on the specific growth rates of T. suecica, (panels A, B) T. weissflogii (panels C, D) and Synechococcus sp. (panels E, F) cells cultivated at five different sulfate concentrations. Error bars indicate standard deviations about the mean $(\mathrm{n}=$ 3). 
801 Figure 5. Specific growth rate $(\mu)$ of T. suecica, T. weissflogii, P. reticulatum and

802 Synechococcus sp. cells cultivated individually or in mixed cultures in media mimicking the

803 chemical compositions of Proterozoic, Paleozoic or present day seawater, binned by species.

804 Error bars indicate standard deviations about the mean $(\mathrm{n}=3)$.

805

806 Figure 6. Specific growth rate $(\mu)$ of T. suecica, T. weissflogii, P. reticulatum and

807 Synechococcus sp. cells cultured in media mimicking the chemical compositions of Proterozoic,

808 Paleozoic or present day seawater; binned by treatment. Error bars indicate standard deviations

809 about the mean $(n=3)$.

810 
811 Table 1. Pure and mixed cultures were grown in media constructed to approximate aspects of 812 modern, Paleozoic and Proterozoic seawater. See text for justification of parameters.

813

\begin{tabular}{|c|c|c|c|}
\hline & Present Day & Paleozoic & Proterozoic \\
\hline $\mathrm{P}_{\mathrm{CO}_{2}}$ & $384 \mathrm{ppm}$ & $2500 \mathrm{ppm}$ & $5000 \mathrm{ppm}$ \\
\hline $\mathrm{NO}_{3}{ }^{-}$ & $10 \mu \mathrm{M}$ & $10 \mu \mathrm{M}$ & - \\
\hline $\mathrm{NH}_{4}{ }^{+}$ & - & - & $10 \mu \mathrm{M}$ \\
\hline $\mathrm{SO}_{4}=$ & $28 \mathrm{mM}$ & $14 \mathrm{mM}$ & $3 \mathrm{mM}$ \\
\hline $\mathrm{Fe}$ & $50 \mathrm{nM}$ & $50 \mathrm{nM}$ & $380 \mathrm{nM}$ \\
\hline $\mathrm{Zn}$ & $100 \mathrm{nM}$ & $100 \mathrm{nM}$ & - \\
\hline Mo & $105 \mathrm{nM}$ & $105 \mathrm{nM}$ & $10.5 \mathrm{nM}$ \\
\hline
\end{tabular}






(mM)

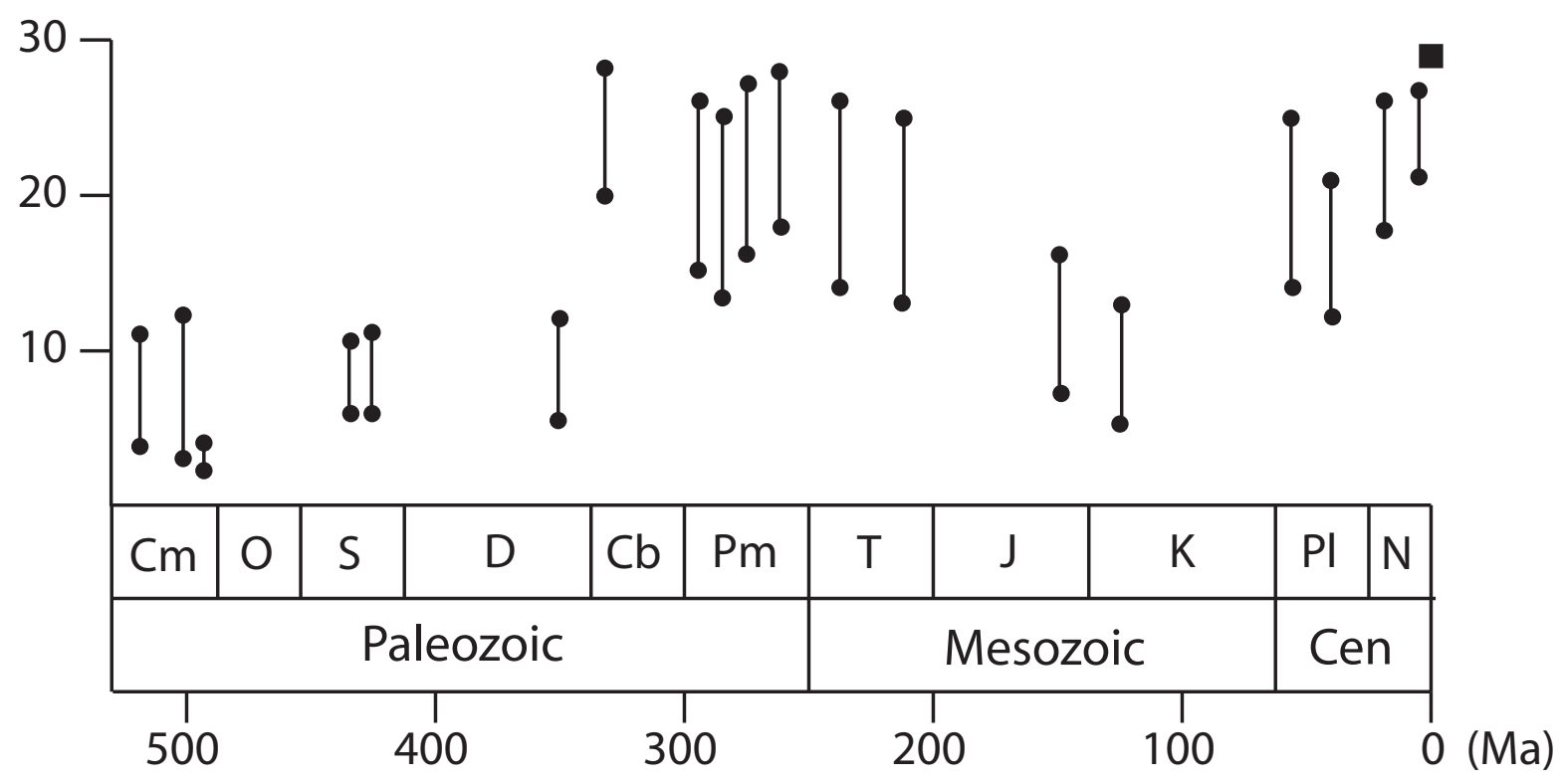




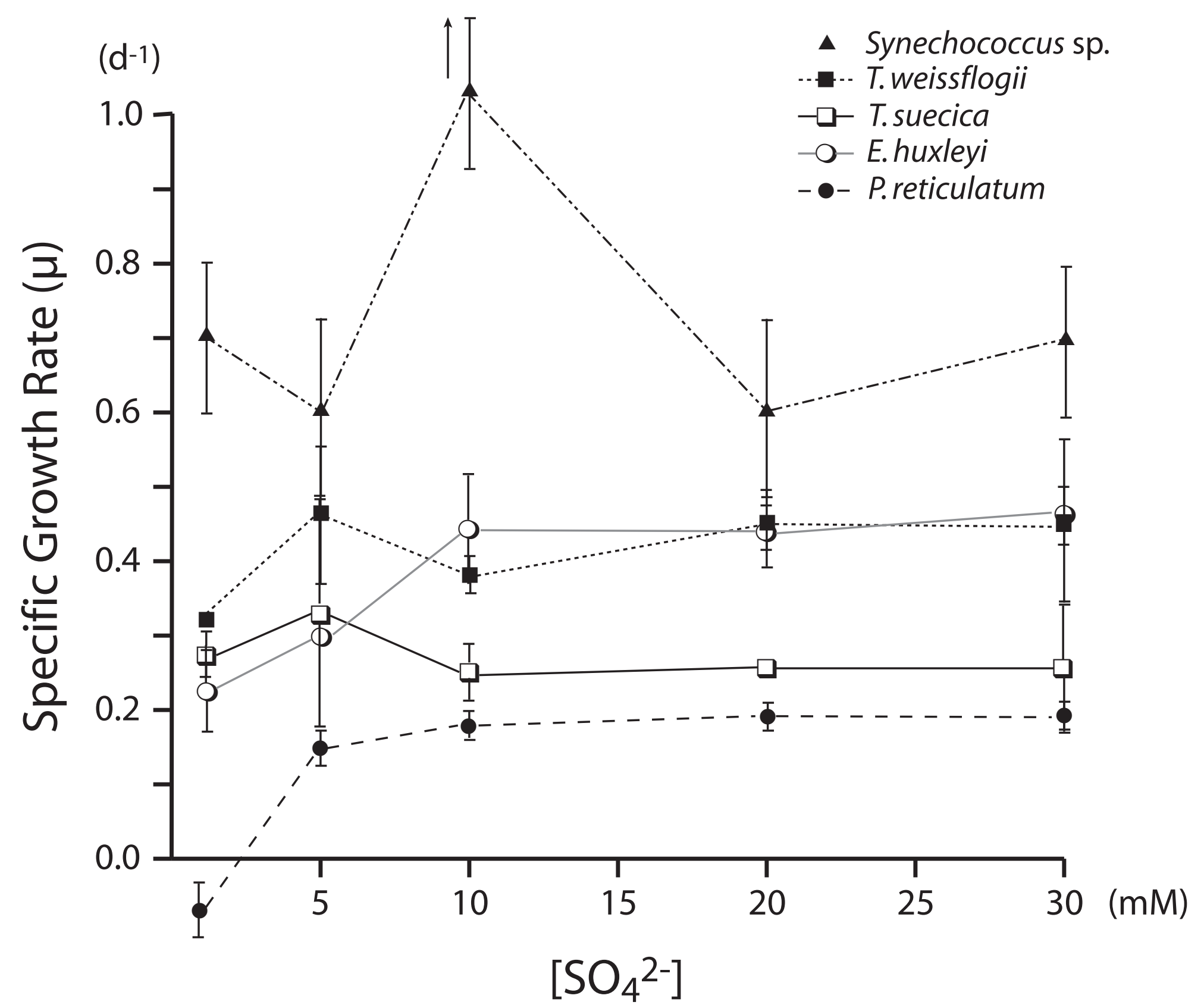



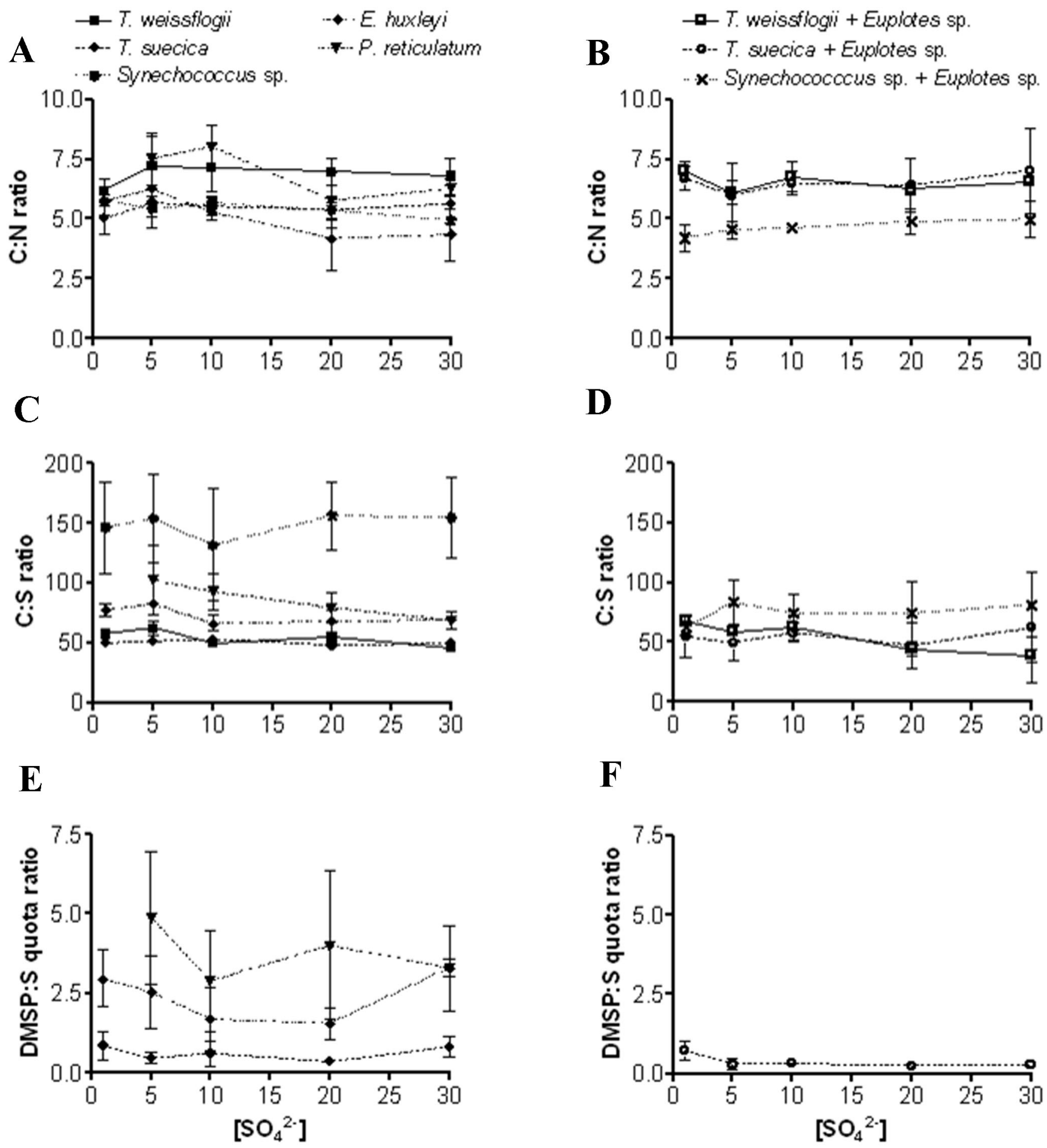
A
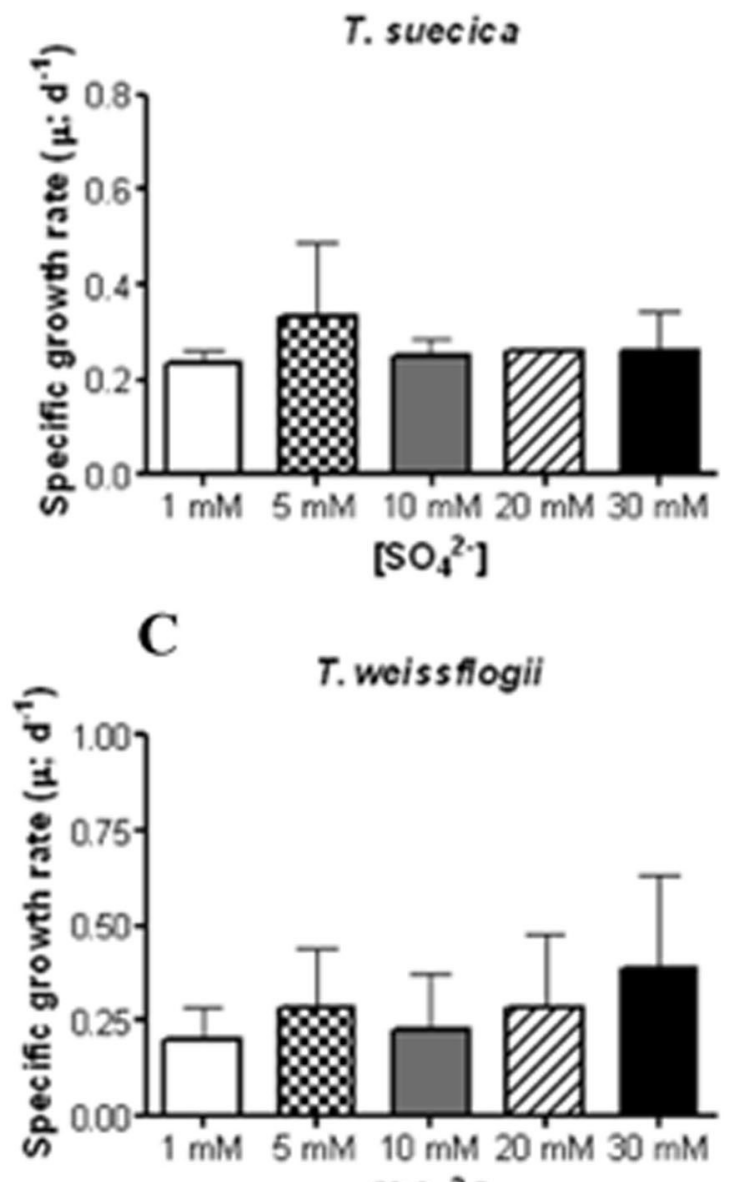

$\left[\mathrm{SO}_{4}{ }^{2}{ }^{2}\right]$

E

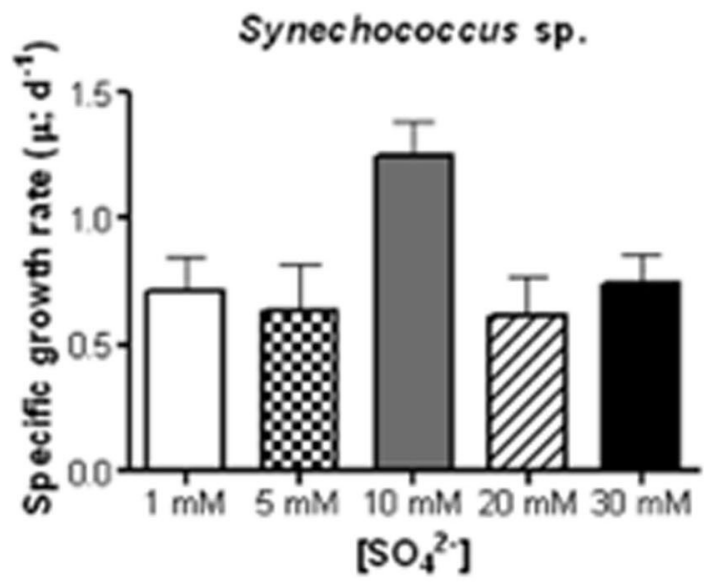

B

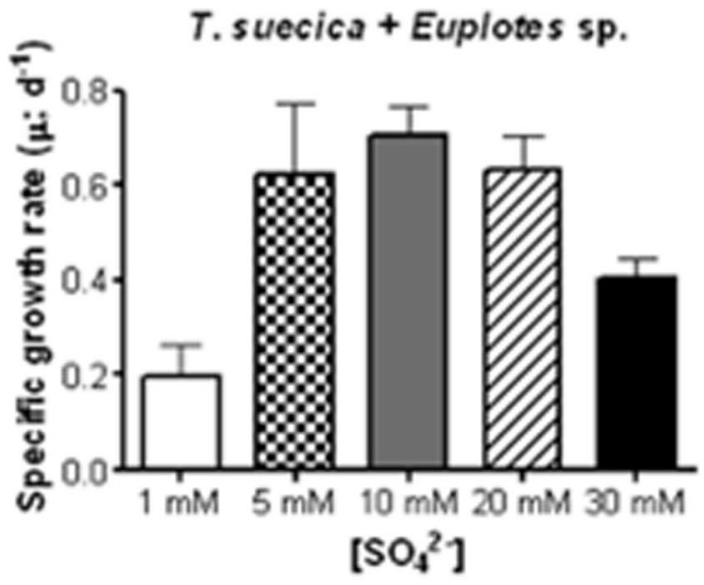

D

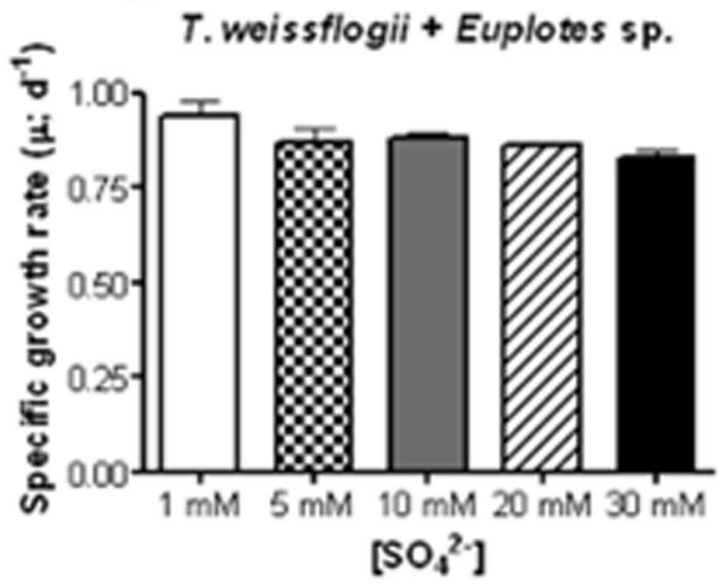

F

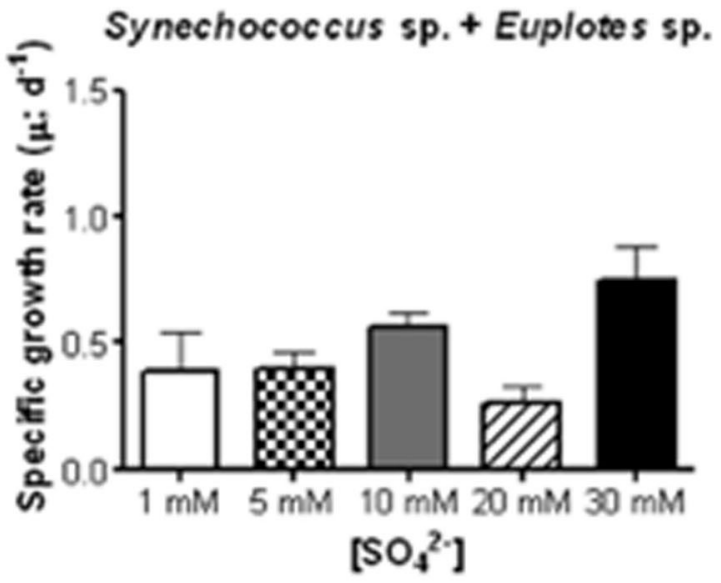




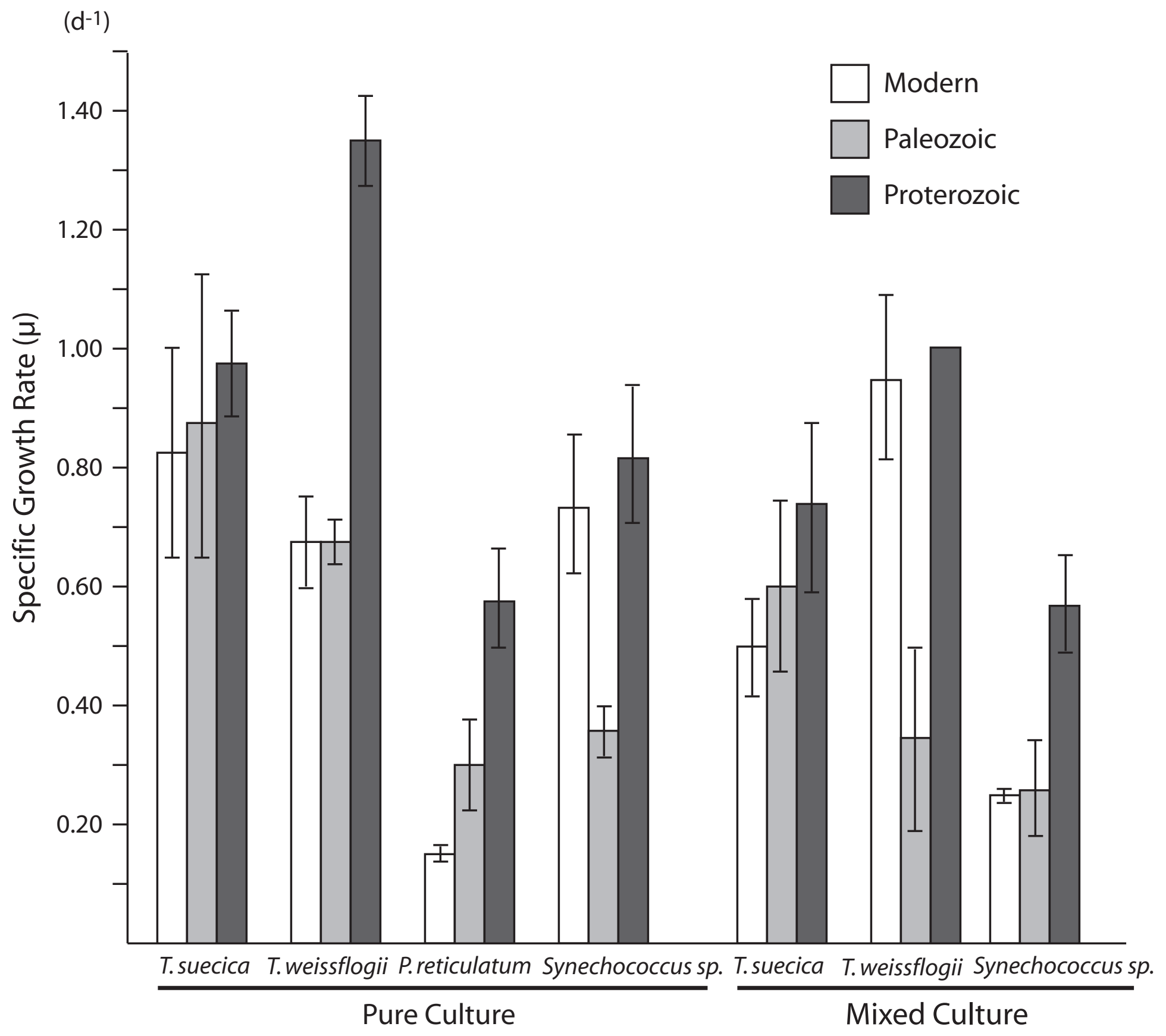




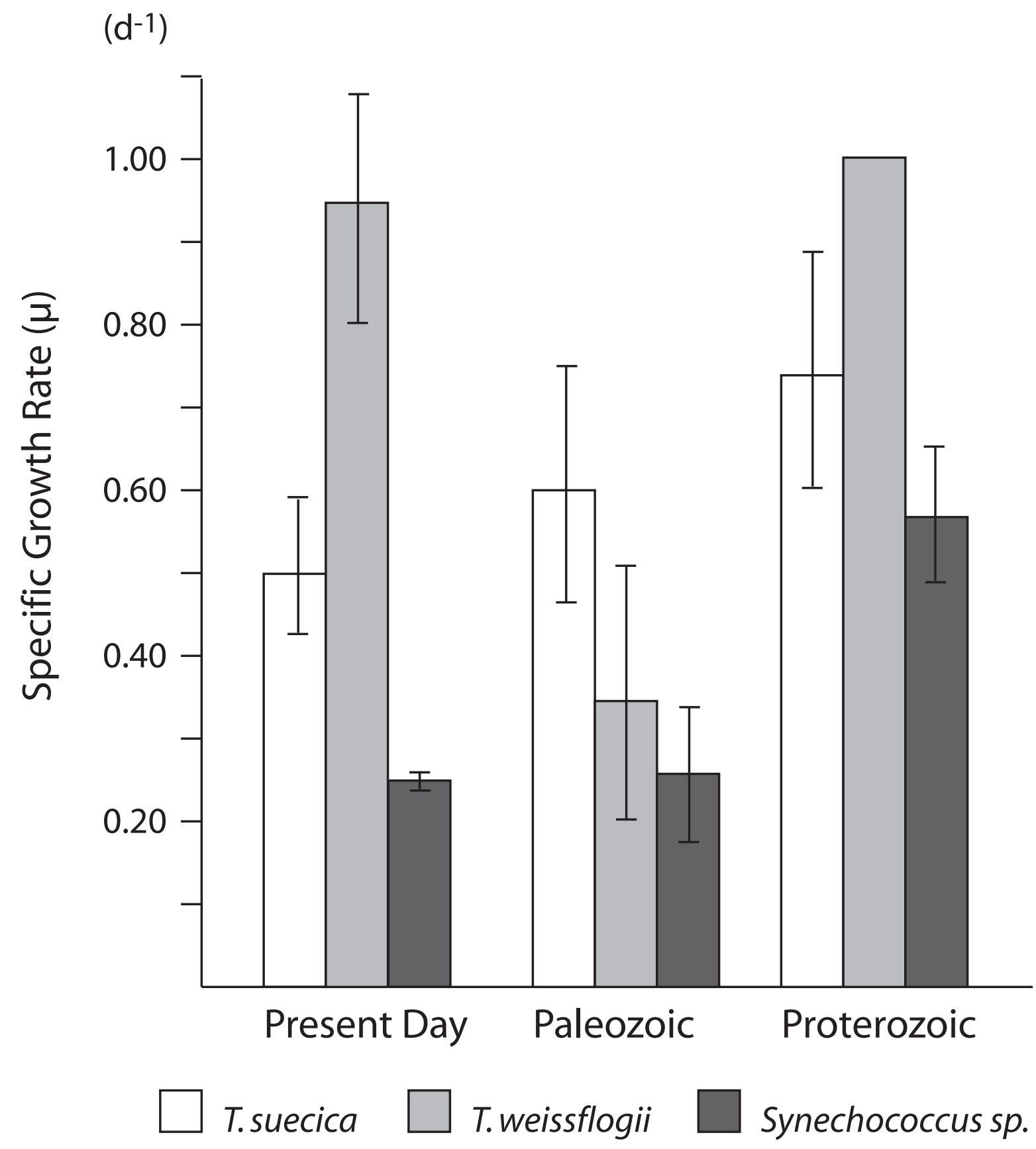

